\title{
Emil Theodor Kocher: an innovator surgeon
}

\author{
María Liliana Franco, MD ${ }^{1}$, Natalia Acosta, Biol ${ }^{2}$, Lilian Chuaire, PhD (c) ${ }^{3}$
}

\section{SUMMARY}

Emil Theodor Kocher is considered along with Frank Lahey, Theodor Billroth, William Halsted, Charles Mayo, George Crile and Thomas Dunhill as one of the «Magnificent Seven», referring to the group of surgeons who managed thyroidectomy to make it a safe and efficient intervention that it is now practiced throughout the world. He was author of numerous contributions towards medicine. One of his most important contributions was to elucidate the function of the thyroid gland, through the observation and study of thyroidectomyzed patients, for which he was recognized by the academic and scientific community during the early twentieth century.

Keywords: Thyroidectomy; General surgery; History of medicine.

\section{Theodor Kocher: un cirujano innovador}

\section{RESUMEN}

Theodor Emil Kocher es considerado junto con Frank Lahey, Theodor Billroth, William Halsted, Charles Mayo, George Crile y Thomas Dunhill como uno de los llamados «Siete Magníficos» en alusión al grupo de cirujanos que lograron hacer de la tiroidectomía la intervención eficiente y segura que en la actualidad se practica en el mundo entero. Autor de innumerables aportes al arte de la medicina, quizás su contribución más importante fue haber dilucidado la función de la glándula tiroides, por medio de la observación y del estudio del estado de sus pacientes tiroidectomizados, hallazgo que le hizo acreedor del reconocimiento de la comunidad académica y científica de los comienzos del siglo XX.

Palabras clave: Tiroidectomía; Cirugía general; Historia de la medicina.

Emil Theodor Kocher was the first surgeon awarded with the Nobel Prize in the field of physiology and medicine. The distinction was granted by the Nobel Committee in December the $11^{\text {th }}$ of 1909 due to «his work in physiology, pathology, and thyroid gland surgery» ${ }^{2}$, which allowed him the discovery of its function throughout the excision or removal of this gland.

During the nineteenth century, this procedure was essential not only to prove the gland's function, but of the majority of organs and tissues. For this reason it constituted a remarkable tool for the understanding and treatment of innumerable diseases. This issue becomes very important if it is considered the fact that at those moments, surgery was not seen as a part of medical discipline. Instead, it was set as a manual skill exerted by practitioners whose expertise could only be demonstrated when they made procedures such as manipulating broken bones, skin tumor excisions or removing boils. Even more, the effectiveness of surgical procedures in treating diseases was not recognized.

This generated rejection towards the surgeon's image because collectively it was unconsciously related to pain, infection ${ }^{3}$, and high mortality rates ${ }^{4}$. Due to this, surgery was not considered a prestigious profession as medicine alone.

At times in which there were wrong beliefs regarding human health -inherited straight from Galen- events as the introduction to histopathology by Johannes Müller (1801-1858) and Alfred Donné (1801-1878) and to

1. Medical doctor, Universidad del Rosario, Bogotá DC, Colombia.e-mail: marialilianaf85@hotmail.com

2. Biologist, Facultad de Ciencias, Pontificia Universidad Javeriana, Bogotá DC, Colombia.e-mail: natalializ@yahoo.com

3. Principal Professor, Facultad de Ciencias Naturales y Matemáticas, Universidad del Rosario, Bogotá DC, Colombia. e-mail: lilian.chuaire@gmail.com

Received for publication March 6, 2008 Accepted for publication April 14, 2009 


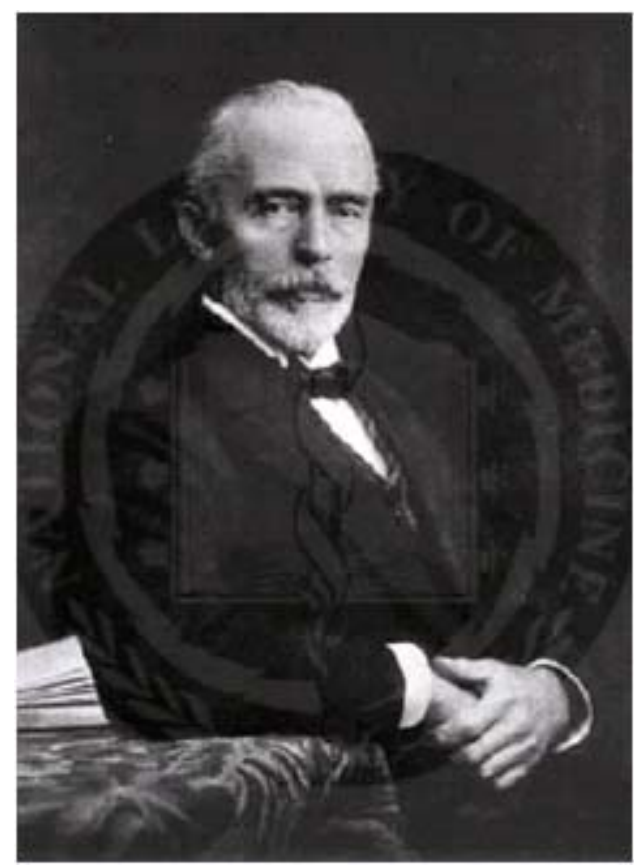

Emil Theodor Kocher 1841-1917

general anesthesia by John Collins Warren (1778-1856), Horace Wells (1815-1848) and William Thomas Green Morton (1819-1868), as well as the advances in antiseptics and new techniques in head and neck surgery, developed by great surgeons as Kocher, Billroth, von Langenbeck and von Volkmann, did not just mark a breakpoint with traditional medicine, but they constituted a huge step towards a new era in which the already mentioned, Kocher, found an appropriate scenario for the development of his glowing career ${ }^{5}$. Along with his colleagues, Kocher contributed towards the recognition of surgery as an invaluable tool used in the detection of disorders produced by sick organs or tissues throughout the restoration of their function or their removal ${ }^{3}$. This made surgery inseparable from medicine ${ }^{5}$ and turned it into an essential element in the treatment of certain diseases, which until that very moment could only be medically treated or by means of radical changes in lifestyle or throughout relatively harmless methods such as inducing vomit, using purgative substances or bleeding ${ }^{3}$.

Before 1872, year in which Kocher performed his first thyroidectomy, the prevalence of thyroid hypertrophy in Berne, Switzerland, his hometown, was extremely high and the mortality rate related to surgical intervention reached about $75 \%$. The most frequent complications included damage of the recurrent laryngeal nerve and post operatory tetany due to removal of parathyroid glands ${ }^{6}$. His mentor and namesake, Billroth, who had had problems with post operatory tetany, decided to end up with thyroid surgery, in answer perhaps to several voices that had risen up against the procedure. For instance, Diffenbach in Germany had judged it for what he believed it was «one of the most thankless and dangerous» also «reckless» and he argued that if it wasn't forbidden once and for all, at least it should be controlled ${ }^{7}$. While in France thyroidectomy was prohibited by the Medicine Academy of the time, in America, Gross referred to it as a «horrible butchery, deserving reproach and conviction», in which "not $a$ honest or sensitive surgeon should be involved ${ }^{8}$. With such history and aware about the high mortality rate observed throughout the thyroidectomies that he made during the following ten years $(12.8 \%$ of 101 in total), as well as of the undesirable clinical condition in which some of his patients were left $i^{9}$, it was not strange that Kocher limited the number of his interventions until he had more knowledge regarding thyroidal function which would let him refinehis technique. He made this decision in 1874 after he had a successful intervention in an eleventh year old female patient who soon after surgery began to show signs of tiredness and lack of initiative. As pictures of the time show, before the patient's surgery, she was taller than her younger sister $^{2}$. However, nine years later, her height was much more reduced and had cretinoid appearance ${ }^{2}$. It was not until he realized a possible association between her clinical picture and the one caused by iodine deficiency described by Virchow, when Kocher decided to modify his technique even though he did not fully know the details of such relation. In 1883 he perfectioned the technique throughout the preservation of a small portion of the glandular tissue. For instance it could be a complete lobe, to ensure a minimal hormonal secretion and avoid the appearance of post operatory myxedema ${ }^{10}$. He used to save radical interventions for cases of untreatable compression or cancer ${ }^{1}$. He based this on his personal experience which proved him in part, that the removal of goiter was the cause of what he called «cachexia thyreopriva» that was similar to congenital hypothyroidism in its symptoms. Moreover, it proved that partial excision, or «thyroid juice» supply, lowered the symptoms ${ }^{4}$. 
Meanwhile, Ord, who defined the term myxedema, made research in thyroid function along with Kocher. After discovering that thyroid follicles of postmortem tissues did not contain colloid but instead they had a fibrous material, Ord associated the myxedematous state with the thyroid gland. However, it was until 1883 that the thyroidal function was totally cleared up thanks to the results obtained by Semon, who proposed that the fall in the activity of such organ was the origin of both Ord's myxedema and Kocher's cachexia thyreopriva, the same as Gull's cretinism. That same year, Kocher published his observations about the results of total thyroidectomy ${ }^{1}$.

Kocher also ventured extraordinarily in treating patients with exophthalmic goiter which had been described before by Graves ${ }^{11}$. In order to reduce the thyroid activity of these patients, Kocher designed a strategy that consisted of two phases: in the first, he provoked a decrease in the blood flow to the gland, for which he tied up some of its arteries. In the second phase, he performed a partial lobectomy, usually unilateral. He considered a third phase in which he excised some of the remaining lobe. However, he just did it in case the condition persisted or reappeared. The mortality rate related to this procedure was of $4.5 \%$.

He was author of the famous «Kocher's II incision», which was a slightly curve transverse outlined cut, brought about two centimeters above the sternoclavicular articulations ${ }^{2}$. This incision allowed him to work in a «cleaner» way in a field that was practically blood free, in contrast to the initial procedures taught by Billroth, his teacher ${ }^{2}$. By 1912, Kocher had performed about 5000 thyroidectomies with only $0.5 \%$ of mortality ${ }^{12}$.

Kocher was the first with the idea to exchange body parts, or in other words, transplanting organs. In 1883 he tried to reverse the post operatory myxedematous condition of one of his patients, throughout the reinsertion of thyroid tissue. This fact opened the door for surgeons as Mathieu Jaboulay and Alexis Carrel to find ways to replace sick tissues for healthy ones ${ }^{13}$, so they could understand and treat many diseases that were incomprehensible and incurable at the time. The first transplants were made with organs such as pancreas, kidneys, testicles, and ovaries ${ }^{13}$.

Besides laying the basis to identify thyroid function and physiology, Kocher showed an unending concern for health and quality of life of his thyroidectomized patients. Through this, he promoted different methods such as «organotherapy» and the distribution of thyroid extract pills in order to restore the gland's function in such patients ${ }^{14}$.

Kocher contributed in other fields besides surgery which put him at a higher level. For instance, he created a way to reduce shoulder dislocations (Kocher's III method). Moreover, he designed new techniques and instruments to approach other organs as the gallbladder. He empowered the existing techniques for inguinal hernia radical surgery throughout invagination(Kocher's II method) and introduced improvements in the intervention of organs as stomach, lung, and tongue ${ }^{15}$.

Kocher performed successful surgeries due to his deep knowledge in anatomy and physiology and precision in surgical techniques. In this way he contributed in shifting the point of view about the surgeon's job at the beginning of the twentieth century.

Emil Theodor Kocher was one of the most important exponents of thyroid surgery. He inspired a new surgical school based on his refined technique. He transferred his concepts to other recognized surgeons in Europe and America, such as Charles Mayo, who was pioneer of endocrinologic surgery in America. Kocher's ideas and his observations about the results of his interventions were crucial not only for physiology and surgery, but for the rising of medical endocrinology ${ }^{16,17}$.

\section{REFERENCES}

1. Hannan SA. The magnificent seven: a history of modern thyroid surgery. Int J Surg. 2006; 4: 187-91.

2. Hamburger B. Emil Theodor Kocher 1997. (fecha acceso: agosto 8 2008). En: Nobelprize.org Disponible en: http://nobel prize.org

3. Schlich T. Nobel Prizes for surgeons: In recognition of the surgical healing strategy. Int J Surg. 2007; 5: 129-33.

4. Raju TNK. The Nobel Chronicles. Lancet. 1998; 352: 746-7.

5. Folz BJ, Silver CE, Rinaldo A, Fagan JJ, Pratt LW, Weir N, et al. An outline of the history of head and neck oncology. Oral Oncol. 2008; 44: 2-9.

6. Ziegler MM. Nobel Laureates in surgery. En: Souba WW, Wilmore DW ed. Surgical Research. San Diego: Academic Press, Elsevier Inc; 2001. p. 1287-97.

7. Diffenbach JF. Die Operative Chirurgie II. Leipzig: FA Brockhaus; 1848. p. 331. Citado por: Hannan SA. The magnificent seven: a history of modern thyroid surgery. Int $J$ Surg. 2006; 4: 187-91.

8. Gross SD. A system of surgery. 4th ed. Philadelphia: Lea \& Febiger; 1866. p. 394. Citado por: Hannan SA. The magnificent seven: a history of modern thyroid surgery. Int J Surg. 2006; 
4: 187-91.

9. Biografía de Emil Theodor Kocher. En Biografías y Vidas. (Fecha de acceso: agosto 8 de 2008). Disponible en: http:// www.biografiasyvidas.com

10. Haas LF. Emil Theodor Kocher (1841-1917). J Neurol Neurosurg Psychiatry. 2000; 69: 171.

11. Graves RJ. Newly observed affection of the thyroid gland in females. Lond Med Surg J. 1835; 7: 516. Citado por: Hannan SA. The magnificent seven: a history of modern thyroid surgery. Int J Surg. 2006; 4: 187-91.

12. Shampo MA. Emil Theodor Kocher. Innovative Surgeon. $J$ Pelvis Surg. 2001; 7: 34-6.

13. Jaboulay M. Greffe de reins au pli du coude par soudures artérielles et veneuses. Lyon Médical. Rev Lyon Med. 1906;
107: 399-400. Citado por: Schlich T. Nobel Prizes for surgeons: In recognition of the surgical healing strategy. Int J Surg. 2007; 5: 129-33.

14. Droin G. Endemic goiter and cretinism in Alps: evolution of science and treatments, transformation of the phatology and its representations. Int J Anthropol. 2005; 20: 307-24.

15. Kazi RA. Theodor E. Kocher. J Postgrad Med. 2003; 49: 3712.

16. Irvin MM. Surgical triumvirate of Theodor Kocher, Harvey Cusher, and William Halsted. World J Surg. 1998; 2: 103-13.

17. Liebermann-Meffert D. Short story of Theodor Kocher's life and relationship to the international society of surgery. World J Surg. 2000; 24: 2-9. 